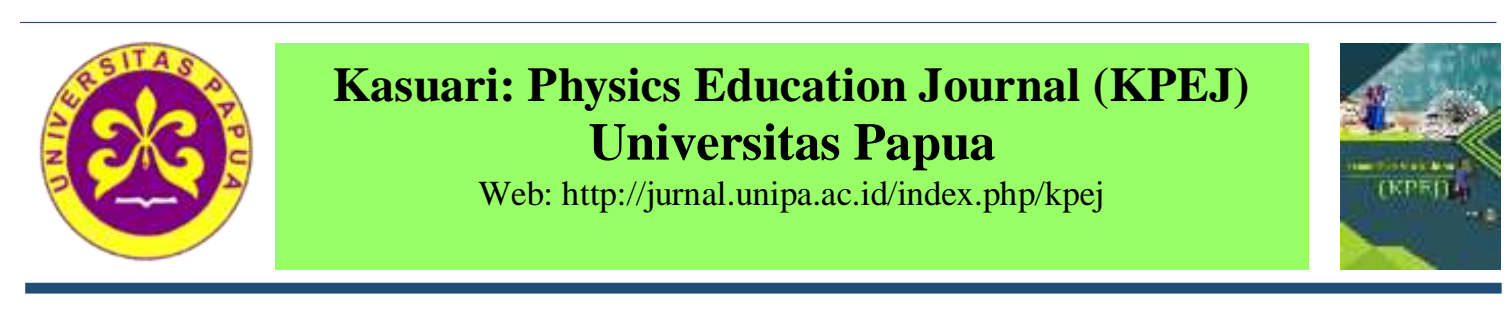

\title{
The Effect of TGT Cooperative Learning on Student Learning Achievement Physics Class XI SMAN 1 Tugumulyo
}

\author{
Eka Maryam \\ Program Studi Teknik Informatika, STMIK Musi Rawas \\ Corresponding author: ekamaryam996@gmail.com
}

\begin{abstract}
This study aims to determine the achievement of physics learning using Teams Games Tournaments (TGT) model and find out an increase or gainscore between experimental classes using Team Games Tournamens model with control class using whiteboard. Conducting research in SMAN 1 Tugumulyo with sample 48 students, consisting of 25 students class XIAI as experiment class and 23 students X1 A2 as control class. The type of this research is quasi experimental design. The data collection technique used is objective test. The statistical prestation test (t-test) used in this research is homogeneous test and normality data test. The results showed that: 1) the experimental class experienced an increase in learning achievement between before and after using TGT model, 2) the increase or gainscore in the experimental class is 5,0 and the gain score of the control class is 4,24. So it can be concluded TGT model can affect student achievement.
\end{abstract}

Keywords: TGT model, learning achievement

\section{Pengaruh Model Pembelajaran Koperatif TGT terhadap Prestasi Belajar Fisika Peserta Didik Kelas XI SMAN 1 Tugumulyo}

\begin{abstract}
Abstrak: Penelitian ini bertujuan untuk mengetahui prestasi belajar fisika menggunakan model Teams Games Tournaments (TGT) dan mengetahui peningkatan atau gainscore antara kelas eksperimen yang menggunakan model TGT dengan kelas kontrol yang menggunakan papan tulis. Pelaksanaan penelitian di SMAN 1 Tugumulyo dengan sampel 48 peserta didik yang terdiri dari 25 peserta didik kelas XI A1 sebagai kelas eksperimen dan 23 peserta didik X1 A2 sebagai kelas kontrol. Jenis penelitian ini adalah kuasi eksperimen (quasi experimental design). Teknik Pengumpulan data yang digunakan adalah tes objektif. Statistik yang digunakan dalam penelitian ini yaitu uji t-test. Hasil penelitian menunjukan bahwa: 1) pada kelas eksperimen mengalami kenaikan prestasi belajar antara sebelum dan sesudah menggunakan model pembelajaran TGT, 2) peningkatan atau gainscore pada kelas eksperimen adalah 5,0 dan gain score kelas kontrol 4,24. Sehingga dapat disimpulkan model pembelajaran TGT dapat mempengaruhi prestasi belajar peserta didik.
\end{abstract}

Kata kunci: model TGT, hasil belajar

\section{PENDAHULUAN}

Pendidikan merupakan suatu proses pembentukan kepribadian manusia. Sebagai suatu proses pendidikan tidak hanya berlangsung pada satu saat saja, akan tetapi berlangsung secara berkelanjutan tanpa dibatasi adanya usia atau pendidikan seumur hidup (long life education). Pendidikan menjadi suatu yang sangat penting untuk meningkatkan kualitas sumber daya manusia agar mampu bersaing dengan sesamanya. Pembelajaran saat ini seharusnya berpusat terhadap peserta didik (student center) bukan berpusat terhadap guru (teacher center). Guru lebih banyak memberikan materi pelajaran melalui metode ceramah, sedangkan peserta didik hanya pasif dan mendengarkan, sehingga pembelajaran 
terkesan membosankan dan membuat peserta didik tidak berkonsentrasi dalam mengikuti proses pembelajaran. Penyebab nilai rendah dipengaruhi oleh beberapa faktor, di antaranya kemampuan masing-masing peserta didik rendah, kurangnya minat peserta didik dalam proses pembelajaran, partisipasi peserta didik yang masih rendah dalam proses pembelajaran dan disebabkan karena metode ceramah yang digunakan oleh guru membuat peserta didik bosan sehingga mengantuk dalam proses pembelajaran (Sa'adah, 2017). Kurang bervariasinya guru dalam menggunakan metode atau model pembelajaran membuat peserta didik tidak memiliki minat dalam mengikuti pembelajaran di kelas yang berdampak terhadap hasil belajar peserta didik yang rendah. Kegiatan Belajar Mengajar (KBM) dapat berjalan dengan baik apabila guru mampu menggunakan strategi pembelajaran yang sesuai dengan kebutuhan peserta didik di dalam kelas. Strategi pembelajaran menekankan pada peranan atau tanggung jawab guru dalam mendorong keberhasilan peserta didik dalam belajar. Keberhasilan belajar dapat dicapai melalui berbagai model pembelajaran yang salah satunya model pembelajaran koperatif.

Model koperatif adalah model pembelajaran yang secara sadar dan sengaja mengembangkan interaksi yang saling asuh antar peserta didik untuk menghindari ketersinggungan dan kesalahpahaman yang dapat menimbulkan permusuhan. Menurut (Simsek, dkk. 2013) model pembelajaran kooperatif adalah salah satu model pembelajaran yang mengedepankan belajar mengenal, belajar melakukan, belajar menjadi dan belajar hidup bersama. Pada penelitian ini model pembelajaran yang digunakan adalah model koperatif tipe Teams Games Tournament (TGT) karena model pembelajaran TGT tidak hanya dapat mengembangkan prestasi akademik peserta didik, melainkan juga dapat meningkatkan keterampilan sosial peserta didik dalam berinteraksi di kelas serta menciptakan suasana belajar yang menyenangkan di kelas. Hal ini sesuai dengan pendapat (Nadrah, dkk, 2017) para peserta didik memiliki motivasi kuat untuk belajar fisika yang diajarkan menggunakan pembelajaran kooperatif dengan tipe TGT.

TGT adalah suatu tipe pembelajaran kooperatif yang menempatkan peserta didik dalam kelompok-kelompok belajar yang beranggotakan 5 sampai 6 orang peserta didik yang memiliki kemampuan, jenis kelamin, dan suku kata atau ras yang berbeda, sehingga peserta didik dapat saling membantu dalam menyelesaikan permasalahan pembelajaran yang dihadapi. Dalam penelitian ini, hal yang menjadi rumusan masalah adalah apakah metode pembelajaran koperatif tipe TGT dapat meningkatkan prestasi belajar peserta didik kelas XI-IPA SMA Negeri 1 Tugumulyo tahun pelajaran 2017/2018?. Tujuan yang ingin dicapai dalam penelitian ini adalah mengetahui metode pembelajaran kooperatif tipe TGT terhadap prestasi belajar peserta didik kelas XI IPA SMA Negeri 1 Tugumulyo tahun pelajaran 2017/2018.

\section{LANDASAN TEORI}

\section{Belajar}

Belajar adalah suatu proses perubahan tingkah laku individu melalui interaksi dengan lingkungan sehingga terjadi perubahan yang lebih baik. Sedangkan pembelajaran adalah suatu proses yang terdiri dari kombinasi dua aspek yaitu belajar yang berorentasi pada peserta didik dan mengajar berorentasi pada guru (Muslich, 2011). Menurut Gagne (Sagala, 2012) mengungkapkan bahwa prinsip dasar pembelajaran yaitu membantu menumbuhkan potensi dalam diri peserta didik sehingga mampu memahami konsep ataus prinsip dalam kajian ilmu yang dipelajarinya yang akan terlihat dalamkemampuannya untuk berpikir logis, kritis, dan kreatif. Dari penjelasan tersebut maka pembelajaran dapat disimpulkan sebagai proses atau kegiatan peserta didik belajar yang direncanakan, dilaksanakan, dan dievaluasi oleh guru secara sistematis agar peserta 
didik dapat belajar dalam situasi dan kondisi yang kondusif dan efektif serta dengan hasil yang optimal sehingga tingkah laku peserta didik dapat berubah ke arah yang lebih baik.

\section{Prestasi Belajar}

Prestasi dalam kamus besar bahasa indonesia memiliki arti hasil yang telah dicapai. Sedangkan belajar adalah proses perubahan tingkah laku individu dengan lingkungan menuju perubahan yang lebih baik, Maka prestasi belajar dapat diartikan sebagai hasil belajar yang telah dicapai oleh peserta didik dalam mengikuti proses belajar mengajar atau KBM. Prestasi ini dalam berbentuk nilai yang diberikan oleh guru kepada peserta didik. Pemberian nilai ini berfungsi untuk melihat sejauh mana penguasaan materi oleh peserta didik tersebut dan juga sebagai tolok ukur keberhasilan suatsu kegiatan pembelajaran. Prestasi belajar dipengaruhi beberapa faktor dari dalam dan faktor dari luar. Hal ini senada dengan pendapat (Mirhadizadeh, 2016) prestasi belajar dipengaruhi faktor intern dan faktor ekstern. Faktor intern adalah faktor yang dialami dan dihayati secara langsung peserta didik dan berpengaruh terhadap proses pembelajaran dalam pencapaian prestasi belajar. Faktor intern ini meliputi: 1) sikap peserta didik terhadap belajar, 2) motivasi belajar, 3) konsentarasi belajar, 4) kemampuan mengolah bahan belajar, 5) kemampuan menyimpan perolehan prestasi belajar, 6) kemampuan menggali prestasi belajar yang telah tersimpan, 7) kemampuan berprestasi atau unjuk prestasi belajar, 8) rasa percaya diri peserta didik, intelegensi dan keberhasilan belajar dan kebiasaan belajar.

\section{Pembelajaran Kooperatif}

Pembelajaran fisika dapat diserap dengan baik oleh peserta didik jika strategi dan metode pembelajaran yang diterapkan tepat. Guru perlu memilih model pembelajaranyang tepat dengan kondisi peserta didik. Pemilihan model dan pendekatan pembelajaran disesuaikan juga dengan fasilitas yang terdapat di sekolah. Model pembelajaran adalah suatu rencana yang dapat digunakan untuk membuat kurikulum (rencana pembelajaran jangka panjang) dan merancang bahan-bahan pembelajaran dengan membimbing pembelajaran di dalam kelas (Rusman, 2011). Sedangkan model pembelajaran berdasarkan teori belajar meliputi model interaksi sosial, model pemrosesan informasi, model personal dan model pembelajaran modifikasi tingkah laku (behavioral). Model pembelajaran yang meliputi interaksi sosial peserta didik salah satunya adalah model pembelajaran kooperatif.

Model pembelajaran kooperatif dapat dilaksanakan dengan membantu peserta didik belajar dalam bentuk kelompok-kelompok kecil dengan tingkat kemampuan kognitif yang heterogen. Hal ini sesuai dengan pendapat Isjoni (2009) mengemukakan bahwa pembelajaran kooperatif adalah model pembelajaran yang mengelompokan peserta didik dengan maksud untuk mengembangkan interaksi antar peserta didik yang terintegrasi dan bermuatan akademik. Menurut Simsek, dkk (2013) yang terpenting dari metode kooperatif adalah belajar bersama. Menurut Rusman (2011) terdapat empat hal penting dalam strategipembelajaran kooperatif, yaitu: a) setiap kelompok harus bekerjasama, b) adanya aturan (role) dalam pembelajaran kooperatif yang harus diikuti peserta didik, sehingga pembelajaran dapat mencapai tujuan yang diharapkan, c) adanya upaya belajar dalam kelompokdalam pembelajaran koopertif peserta didik dituntut untuk menyumbangkan idedan memberi tanggapan atas ide peserta didik lain. Hal ini merupakan wujud dari upaya peserta didik untuk belajar dalam kelompok, dan d) adanya kompetensi yang harus dicapai, termasukpembelajaran kooperatif. Penerapan strategi 
model kooperatif bertujuan agar peserta didik mampu mencapaikompetensi yangditetapkan.

\section{Team Games Tournament (TGT)}

Teams Games Tournament (TGT) merupakan model pembelajaran yang tidak hanya dapat mengembangkan prestasi akademik peserta didik, melainkan juga dapat meningkatkan interaksi sosial di kelas. Tidak hanya itu, model pembelajaran ini dapat meningkatkan solidaritas diantara peserta didik karena dalam pembentukan kelompok, setiap kelompok terdiri dari 5 anggota dengan latar belakang, jenis kelamin dan ras yang berbeda. Menurut Slavin (2006), model TGT ini melibatkan beberapa kegiatan yaitu kegiatan pertama adalah penyajian kelas atau presentasi kelas (class precentation) yang disampaikan oleh guru dengan materi secara garis besar. Kegiatan kedua adalah bekerja dalam tim yang meliputi diskusi dengan diberikan lembar kegiatan peserta didik yang memicu interaksi peserta didik dalam belajar, sehingga peserta didik dapat menjadi tutor bagi peserta didik lain dengan kemampuan sedang atau kurang. Dalam kegiatan ini, peserta didik memperoleh kesempatan untuk mempresentasikan hasil diskusi mereka di depan kelas, sehingga keberanian peserta didik serta kepercayan diri peserta didik dapat dikembangkan melalui kegiatan ini.

Jiwa kepemimpinan peserta didik dapat dilihat dari peserta didik yang berani mewakili timnya untuk menyampaikan hasil yang telah didiskusikan pada kelompoknya. Selain itu, peserta didik lain diberi kesempatan menyampaikan gagasan atau pendapatnya jika hasil diskusi dari peserta didik yang dipresentasikan belum tepat. Kegiatan selanjutnya adalah game tournament. Game ini merupakan tujuan utama setiap kelompok untuk mendapat gelar super team. Dengan tujuan ini, setiap anggota kelompok akan berusaha untuk melakukan yang terbaik dalam mengikuti game. Setiap anggota kelompok memiliki peran yang sama dalam perolehan poin game tournament sehingga tidak ada anggota kelompok yang hanya diam dan bergantung pada anggota kelompok tim mereka masing-masing. Dengan game ini diharapkan kepercayaan diri setiap peserta didik meningkat serta dapatterbentuk persaingan yang sehat dan jujur diantara tim.

Kegiatan terakhir adalah rekognisi tim. Dalam rekognisi tim, guru memberikan kepercayaan kepada peserta didik untuk menghitung poin yang diperoleh selama game tournament. Pada kegiatan ini, kejujuran peserta didik sangat dibutuhkan karena dalam pelaksanaannya, guru hanya mengawasi pelaksanaan rekognisi tim secara keseluruhan. Selebihnya penskoran game merupakan tanggung jawab untuk setiap peserta didik. Pemberian penghargaan diberikan kepada tim yang memperoleh poin terbanyak dalam game tournament merupakan bentuk apresiasi terhadap kemampuan peserta didik yang bekerja dalam tim.

\section{METODE PENELITIAN}

Penelitian ini menggunakan metode kuasi eksperimen (quasi experimental design). Desain penelitian yaitu Randomized Control-Group Pretest-Posttest Design (Sugiyono, 2011). Variabel dalam penelitian ini yaitu model pembelajaran TGT sebagai variabel bebas (variable independent) dan prestasi belajar sebagai variabel terikat (variable dependent). Desain Randomized Control-Group Pretest-Posttest Design menggunakan pretest dan posttest untuk pengambilan data, dua kelompok populasi ataupun sampel yang dipilih secara random dijadikan kelompok eksperimen dan kelompok kontrol. Kelompok eksperimen sebelumnya dilakukan pretest kemudian diberi treatment secara berturut-turut. Selanjutnya diberi posttest untuk mengukur hasil belajar kelompok tersebut. Sedangkan kelompok kontrol diberi pretest dan posttest tetapi tidak diberi 
treatment atau tetap menggunakan cara yang biasanya. Menurut Koksal (2013) skema Randomized Control-Group Pretest-Posttest Design dapat digambarkan seperti Tabel 1.

Tabel 1. Randomized Control-Group Pretest-Posttest Design .

\begin{tabular}{|c|c|c|c|}
\hline Group & Pretest & Treatment & Posttest \\
\hline Experimental Group $(R)^{*}$ & $\mathrm{~T} 1$ & $\mathrm{X}$ & $\mathrm{T} 2$ \\
\hline Control Group $(R)$ & $\mathrm{T} 1$ & - & $\mathrm{T} 2$ \\
\hline
\end{tabular}

Keterangan:

Experimental Group : kelas/kelompok yang diberikan perlakuan

Control Group $\quad$ : kelas/kelompok yang tidak diberikan perlakuan

T1 : hasil pretest kelompok eksperimen atau kontrol sebelum diberikan perlakuan

$\mathrm{T} 2$

: hasil posttest kelompok eksperimen atau kontrol setelah diberikan perlakuan

$\mathrm{X} \quad$ : treatment yang diberikan pada kelompok eksperimen

: tidak adanya perlakuan pada kelompok control

Pelaksanakan penelitian ini di SMAN 1 Tugumulyo. Populasi dalam penelitian ini adalah seluruh peserta didik kelas XI IPA. Sedangkan sampel pada penelitian ini adalah 48 peserta didik yang diambil dari populasi dengan teknik pengambilan secara random. Sampel dibagi dalam dua kelas yaitu 25 peserta didik kelas XI A1 sebagai kelas eksperimen dan 23 peserta didik kelas X1 A2 sebagai kelas kontrol. Teknik yang digunakan untuk pengumpulan data dalam penelitian ini yaitu tes objektif. Tes yang yang digunakan berupa tes pilihan ganda yang berjumlah 25 soal. Soal dibuat dengan memperhatikat tingkat kesukaran, daya beda, validitas dan reliabilitas soal dengan tujuan agar benar-benar bisa mengukur kemampuan peserta didik secara riil.

Teknik analis data digunakan untuk merepresentasikan hasil penelitian. Uji analisis menggunakan uji t-tes. Syarat uji t dapat digunakan apabila data penelitian berdistribusi normal dan homogen. Uji hipotesis dilakukan dengan uji t-test. Menurut Sugiyono (2011) uji $t$-test digunakan untuk menguji hipotesis komparatif rata-rata dua sampel sebagaimana pada persamaan (1).

$$
t=\frac{\bar{X}_{1}-\bar{X}_{2}}{\sqrt{\frac{s_{1}^{2}}{n 1}+\frac{s_{2}^{2}}{n 1}}}
$$

Keteramgan:

$t \quad=$ harga $t$ hitung

$\bar{X}_{1}=$ rata-rata sampel 1

$\bar{X}_{2}=$ rata-rata sampel 2

$s_{1}^{2}=$ varian pada sampel 1

$s_{2}^{2}=$ varian pada sampel 2

$n 1$ = jumlah sampel 1

$n 2$ = jumlah sampel 2

Kriteria pengujian dengan taraf signifikansi $5 \%$, jika nilai $t_{\text {hitung. }}>t_{\text {tabel }}$ maka Ho ditolak sedangkan jika $t_{\text {hitung }}<\mathrm{t}$ tabel maka Ho diterima. 


\section{HASIL DAN PEMBAHASAN}

Hasil penelitian yang telah dilakukan menunjukan bahwa nilai pretest pada kelas kontrol diperoleh nilai tertinggi sebesar 4,8 dan nilai terendah sebesar 2,2 dengan modus sebesar 2,8 serta median sebesar 3,3. Adapun rata-rata pada kelas kontrol sebesar 3,4 dengan standar deviasi sebesar 0,8 dan varian 0,6. Sedangkan hasil pada posttest didapatkan nilai tertinggi 8,5 , nilai terendah 6,8 , median 7,3 dan modus 7,3 . Adapun nilai rata-rata posttest 7,6 dengan standar deviasi 0,6 dan simpangan kuadrat atau varian 0,4 . Hasil nilai pretest-posttest peserta didik pada kelas kontrol (XI A2) ditunjukan pada Tabel 2.

Tabel 2. Distribusi Frekuensi hasil nilai pretest peserta didik pada kelas kontrol.

\begin{tabular}{|c|c|c|c|}
\hline \multicolumn{2}{|c|}{ Nilai pretest } & \multicolumn{2}{c|}{ Nilai posttest } \\
\hline Interval & Frekuensi & Interval & Frekuensi \\
\hline $2,2-2,7$ & 4 & $6,8-7,2$ & 3 \\
\hline $2,8-3,3$ & 8 & $7,3-7,7$ & 6 \\
\hline $3,4-3,9$ & 5 & $7,8-8,2$ & 7 \\
\hline $4.0-4,5$ & 5 & $8,3-8,7$ & 6 \\
\hline $4,6-5,1$ & 1 & $8,8-9,2$ & 1 \\
\hline Jumlah & 23 & & 23 \\
\hline
\end{tabular}

Data hasil penelitian pada kelas eksperimen untuk nilai pretest diperoleh nilai tertinggi sebesar 4,3 nilai terendah sebesar 2,2 dengan modus sebesar 3,3 serta median sebesar 3,3. Adapun rata-rata pretest pada kelas eksperimen sebesar 3,4 dengan standar deviasi sebesar 0,5 dan varian 0,2 . Sedangkan hasil pada posttest didapatkan nilai tertinggi 8,8 , nilai terendah 6,8 , median 8,0 dan modus 8,0 . Adapun nilai rata-rata posttest 8,3 dengan standar deviasi 0,3 dan varian 0,6. Hasil nilai pretest-posttest peserta didik pada kelas eksperimen (XI A1) ditunjukan pada Tabel 3.

Tabel 3. Distribusi Frekuensi hasil nilai pre-test dan post-test peserta didik pada kelas eksperimen

\begin{tabular}{|c|c|c|c|}
\hline \multicolumn{2}{|c|}{ Nilai pretest } & \multicolumn{2}{c|}{ Nilai posttest } \\
\hline Interval & Frekuensi & Interval & Frekuensi \\
\hline $2,2-2,6$ & 1 & $6,8-7,2$ & 3 \\
\hline $2,7-3,1$ & 4 & $7,3-7,7$ & 6 \\
\hline $3,2-3,6$ & 12 & $7,8-8,2$ & 3 \\
\hline $3,7-4,1$ & 7 & $8,3-8,7$ & 8 \\
\hline $4,1-4,5$ & 1 & $8,8-9,2$ & 5 \\
\hline Jumlah & 25 & & 25 \\
\hline
\end{tabular}

Tabel 2 dan Tabel 3 juga menunjukkan rendahnya nilai pretest peserta didik. Rendahnya nilai pretest tersebut menunjukkan bahwa peserta didik belum sepenuhnya memahami materi pelajaran. Pembelajaran yang dilaksanakan sebelumnya belum efektif melatih kemampuan berpikir dan aktifitas belajar mereka dalam menyelesaikan persoalan. Kegiatan pembelajaran perlu melibatkan aktifitas peserta didik untuk menemukan sendiri suatu konsep sehingga pemahaman mereka lebih mendalam (Handayani, dkk, 2017). 
Tabel 3 menunjukkan bahwa prestasi belajar peserta didik baik kelas kontrol maupun kelas eksperimen mengalami kenaikan, tetapi kenaikan prestasi belajar pada kelas eksperimen lebih signifikan. Perbedaan hasil tersebut juga terlihat selama kegiatan yaitu peserta didik lebih aktif selama pembelajaran dengan menggunakan model pembelajaran kooperatif TGT. Kerjasama peserta didik juga terjalin dengan baik, mereka berdiskusi dan mencari penyelesaian permasalahan secara kelompok. Pembelajaran kooperatif memungkinkan peserta didik lebih aktif dalam pembelajaran karena mereka saling membantu antara peserta didik yang memahami materi membantu mereka yang belum memahami penyelesaian permasalahan (Chasanah, dkk, 2016). Hasil perbandingan nilai posttest pada kelas eksperimen dan kontrol dapat dilihat pada Gambar 1.

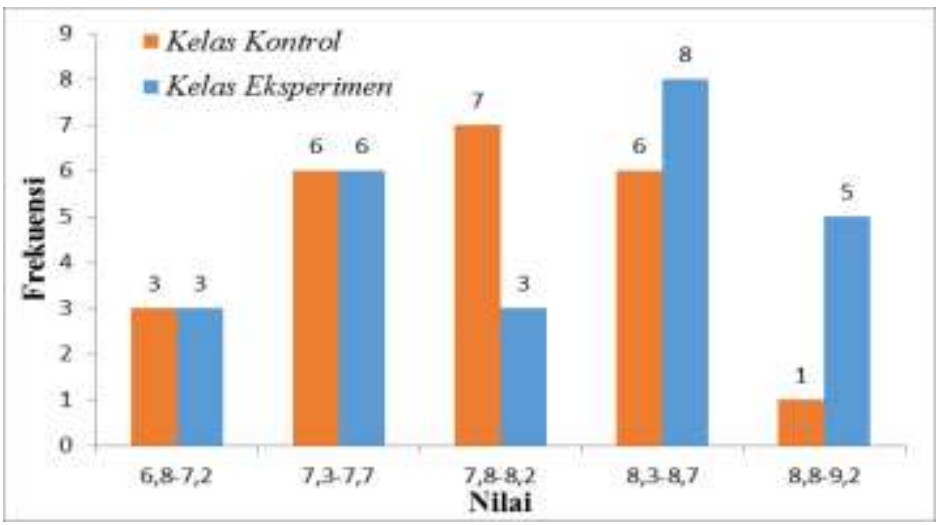

Gambar 1. Perbandingan hasil posttest kelas eksperimen dan kontrol

Gambar 1 menunjukkan bahwa nilai peserta didik cederung lebih tinggi pada kelas eksperimen melalui penerapan model pembelajaran kooperatif tipe TGT dibandingkan pada kelas kontrol melalui pembelajaran konvensional. Hal ini disebabkan karena pada saat pembelajaran melalui model kooperatif TGT, peserta didik aktif mengkaji dan mendiskusikan penyelesaian permasalahan yang diberikan serta mereka dituntut untuk mengkofirmasi pemahamana mereka melalui tahapan turnamen pada akhir pembelajaran. Pembelajaran yang melibatkan aktifitas peserta didik cederung lebih efektif untuk meningkatkan hasil belajar mereka karena mereka dituntut mengkaji dan menemukan sendiri penyelesaian dari permasalahan yang ada (Nadrah, dkk, 2017).

Pengujian hipotesis diawali dengan pengujian terhadap data yang diambil dari satu populasi. Dilakukan pengujian prasyarat analisis yaitu uji homogenitas dan normalitas. Adapun hasil uji homogenitas disajikan pada Tabel 4 dan Tabel 5 menunjukkan hasil pengujian normalitas data.

Tabel 4. Data uji homogenitas varian kelas eksperimen dan kontrol

\begin{tabular}{|c|c|c|c|}
\hline Data & $\mathrm{F}_{\mathrm{h} \text { (Hitung) }}$ & $\mathrm{F}_{\mathrm{t}(\text { Tabel })}$ & Keterangan \\
\hline Eksperimen & 2,58 & 4,26 & Varians Homogen \\
\hline Kontrol & 1,57 & 4,30 & Varians Homogen \\
\hline
\end{tabular}

Tabel 5. Normalitas data kelas Kontrol

\begin{tabular}{|c|c|c|c|c|c|c|}
\hline Data & \multicolumn{3}{|c|}{ Pretest } & \multicolumn{3}{c|}{ Posttest } \\
\cline { 2 - 7 } & $X^{2}{ }_{\text {hitung }}$ & $X^{2}$ tabel & Keterangan & $X^{2}{ }_{\text {hitung }}$ & $X^{2}{ }_{\text {tabel }}$ & Keterangan \\
\hline Eksperimen & 7,76 & 14,60 & $\begin{array}{c}\text { Berdistribusi } \\
\text { Normal }\end{array}$ & 4,37 & 14,60 & $\begin{array}{c}\text { Berdistribusi } \\
\text { Normal }\end{array}$ \\
\hline
\end{tabular}




\begin{tabular}{|c|c|c|c|c|c|c|}
\hline Kontrol & 9,52 & 14,60 & $\begin{array}{c}\text { Berdistribusi } \\
\text { Normal }\end{array}$ & 6,45 & 14,60 & $\begin{array}{c}\text { Berdistribusi } \\
\text { Normal }\end{array}$ \\
\hline
\end{tabular}

Tabel 4 dan 5 menunjukkan bahwa data tersebut homogen dan berdistribusi normal, sehingga analisis uji $t$-test dapat digunakan. Pengujian hipotesis dengan uji t dilakukan untuk mengetahui peningkatan yang signifikan prestasi belajar peserta didik pada hasil pretest dan posttes antara keadaan sebelum perlakuan, kemudian keadaan sesudah pemberian perlakuan. Adapun hasil pengujian hipotesis $t$-test ditampilkan pada Tabel 6.

Tabel 6. Data pengujian hipotesis prettest dan posttest kelas eksperimen.

\begin{tabular}{|c|c|c|c|c|}
\hline Data & Harga t-hitung & Harga t-tabel & Signifikansi & Keterangan \\
\hline Eksperimen & 20,56 & 2,06 & 0,05 & $\begin{array}{c}\text { Ho ditolak dan } \\
\text { Ha diterima }\end{array}$ \\
\hline
\end{tabular}

Pengujian hipotesis menunjukkan hasil bahwa Ha diterima, yaitu terdapat peningkatan secara signifikan prestasi belajar kelompok eksperimen antara prettest dan posttest menggunakan model pembelajaran koopertif tipe TGT. Perbedaan tersebut juga dapat dilihat pada peningkatan gain score yang ditunjukan pada tabel 7.

Tabel 7.Perbedaan peningkatan gain score antara kelas eksperimen dan kelas kontrol.

\begin{tabular}{|c|c|c|c|}
\hline Kelas & prettest & Posttest & Peningkatan/Gainscore \\
\hline Eksperimen & 3,36 & 8,37 & 5,01 \\
\hline Kelas Kontrol & 3,40 & 7,64 & 4,24 \\
\hline
\end{tabular}

Tabel 7 menunjukkan bahwa kelas eksperimen mempunyai peningkatan rerata kelas yang lebih tinggi daripada kelas kontrol yaitu 5,01 sedangkan kelas kontrol 4,24. Hal ini menunjukkan bahwa penggunakan model pembelajaran TGT pada kelas eksperimen berpengaruh terhadap peningkatan prestasi lebih tinggi daripada kelas kontrol yang berselisish 0,77 poin. Selama pembelajaran melalui pembelajaran TGT peserta didik aktif berdiskusi dan menjawab setiap pertanyaan yang diberikan dengan tepat dan kritis. Pembelajaran TGT dapat melatih aktivitas belajar peserta didik dan berdampak positif terhadap hasil belajar mereka (Galura, dkk, 2016).

\section{SIMPULAN DAN SARAN}

Hasil penelitian ini dapat disimpulakan bahwa penenerapan model pembelajaran kooperatif tipe TGT berpengaruh secara signifikan terhadap kenaikan prestasi belajar fisika. Peningkatan prestasi kelas eksperimen yang menerapakan model pembelajaran kooperatif tipe TGT lebih tinggi dengan gainscore 5,01 sedangakan kelas yang menggunakan media papan tulis 4,24. Adapun hal yang dapat disarankan yaitu guru sebaiknya menggunakan model-model pembelajaran yang efektif dan efesien agar proses pembelajaran dapat dituntaskan dengan baik sehingga tidak membosankan untuk guru dan peserta didiknya.

\section{DAFTAR PUSTAKA}

Galura, A., I, Mujasam, \& Widyaningsih, S. W. (2016). Penerapan Model Pembelajaran Kooperatif Tipe Teams Games Tournament (TGT) untuk Meningkatkan Keaktifan dan Hasil Belajar Fisika Peserta Didik Kelas XI IPA di SMA Yapis Manokwari. Pancaran, (5)2, 103-118. 
Handayani, T., Mujasam, Widyaningsi, S. W., \& Yusuf, I. (2017) Penerapan Model Pembelajaran Kooperatif Tipe Snowball Throwing terhadap Hasil Belajar Peserta Didik. Jurnal Curricula, 2(1), 47-58.

Isjoni. (2009). Pembelajaran Kooperatif Meningkatkan Kecerdasan Komunikasi antar Peserta Didik. Yogyakarta: Pustaka Pelajar.

Koksal, M. S. (2013). A Comprehensive Research Design for Experimental Studies in Science Education. Journal İlkögretim Online, 12(3), 628-634.

Kolb, M \& Griffith, S. (2009). "I' Repeat my self, Again?" Empowering Students Through Assertive Communication Strategies. Teaching Exceptional Children, 41(3), 32-36.

Mengduo, Q.\& Xiaoling, J. (2010). Jigsaw Strategy as a Cooperative LerningTeqnique: Focusing on Language Learner. Chinnese Journal of Applied Linguistics (Bimonthly), 33(4), 113-125.

Mirhadizadeh, N. (2016). Internal and External Factors in Language Learning. International. Journal of Modern Language Teaching and Learning, 5(1), 188-196.

Muslich, M. (2011). Pendidikan Karakter Menjawab Tantangan Krisis Multidimensional. Jakarta: Bumi Aksara.

Nadrah, Tolla, I., Ali, M. S., \& Mursi. (2017). The Effect of Cooperative Learning Model of Teams Games Tournament (TGT) and Students' Motivation toward Physics Learning Outcome. International Education Studies, 10(2), 123-130.

Rusman. (2011). Model-Model Pembelajaran Mengembangkan Profesionalisme Guru. Jakarta: Raja Grafindo Persada.

Sa'adah., S. (2017). Implementation of Cooperative Learning Model with Teams Games Tournament (TGT) Method to Improve Interests and Learning Outcomes. Classroom Action Research Journal, 1(2) 11-18.

Sagala, S. (2012). Konsep dan Makna Pembelajaran. Bandung: Alfabeta.

Simsek, U., Yilar, B., \& Kucuk, B. (2013). The Effects of Cooperative Learning Methods on Students' Academic Achievements In Social Psycholo Gy Lessons. International Journal on New Trends In Education And Their Implications, 4(3) $18-27$

Slavin, R. (2006). Educational Psychology (Theory and Practice). Boston Massachussetts: Allyn \& Bacon

Sugiyono (2011). Metode Penelitian Pendidikan. Pendekatan Kuantitatif, Kualitatif, dan $R \& D$. Bandung: Alfabeta.

Sulisworo. D., \& Suryani., D. (2014). The Effect of Cooperative Learning, Motivation and Information Technology Literacy to Achievement. International Journal of Learning \& Development, 4(2), 58-64. 